\title{
Factors associated with the development of preterm children at four and eight months of corrected gestational age
}

\author{
Caroline de Oliveira ${ }^{1}$, Lívia de Castro ${ }^{2}$, Rafaela Silva ${ }^{3}$, Isabella Freitas ${ }^{4}$, \\ Márcia Gomes ${ }^{5}$, Maria Cândida ${ }^{5}$
}

DOI: http://dx.doi.org/10.7322/jhgd.110024

\begin{abstract}
Introduction: The big advances in perinatal care have resulted in longer survival of newborns with lower birth weight. However, these children are at high risk for developmental alterations.

Objective: To analyse the relationship between perinatal variables and the overall development of premature infants at four and eight months of corrected age.

Methods: Longitudinal prospective cohort study where 91 preterm infants with gestational age at or below 34 weeks were followed. The children were evaluated at four and eight months of age by cognitive scales of motor and language with the Bayley Scales of Infant Development III.

Results: Birth weight and bronchopulmonary dysplasia were identified as factors for the permanence in the delayed of overall development. The intervention, after routing, was identified as a factor in the improvement effort. Conclusion: Birth weight below $1,000 \mathrm{~g}$ and bronchopulmonary dysplasia were the main predictive factors for developmental delay. Systematic intervention was a predictive factor for improvement in development.
\end{abstract}

Keywords: premature, child development, risk factors.

\section{INTRODUCTION}

Newborns (NB) are surviving with lower birth weights as a result of scientific and technological advances that have resulted in significant changes in obstetric and neonatal assistance ${ }^{1}$. However, these children are at increased risk of developmental changes ${ }^{2-3}$. It is important to assess the impact of perinatal morbidity variables for identification, ranging from permanent brain damage, such as cerebral palsy, to subtle forms of developmental delay ${ }^{4}$.

The first year of life is important for a child's development, considering that the greatest neuronal plasticity period occurs in this phase. In this context, special care should be aimed at children who are more likely to have problems in this period due to the exposure to risk factors ${ }^{5}$.
The monitoring of the risk of child development should be a continuous and flexible process of assessment, which will act preventively to detect a disability and refer to specific treatment.

Given the importance of the identification delay in development and its relation to infant morbidity, early identification of children at risk is key in order to minimise the resulting negative effects. There is sufficient evidence showing that the earlier the diagnosis of delayed development and the intervention, the lower the impact of these problems in the child's future life ${ }^{5}$. Thus, the objective of this study is to identify factors associated with the overall development of preterm infants at four and eight months of corrected gestational age.

1 Departamento de Terapia Ocupacional, Universidade de Brasília.

2 Departamento de Terapia Ocupacional, Universidade Federal de Minas Gerais.

3 Departamento de Fisioterapia, Universidade Federal de Santa Catarina.

4 Terapeuta Ocupacional.

5 Departamento de Pediatria, Universidade Federal de Minas Gerais.

Corresponding author: Caroline de Oliveira Alves. E-mail: carolineoliveiraalves@gmail.com

Suggested citation: Oliveira C, Castro L, Silva R, Freitas I, Gomes M, Cândida M. Factors associated with the development of preterm children at four and eight months of corrected gestational age. J Hum Growth Dev. 26(1): 41-47. Doi: http://dx.doi.org/10.7322/jhgd.110024 Manuscript submitted: Oct 01 2015, accepted for publication Jan 2016. 


\section{METHODS}

This is a longitudinal prospective cohort study, which investigated the development of children followed from March 2011 to March 2012 at the Follow-up Clinic of Sofia Feldman Hospital in Belo Horizonte, Minas Gerais, Brazil. The Ethics Committee of the Federal University of Minas Gerais, Brazil, and the Maternity Sofia Feld-

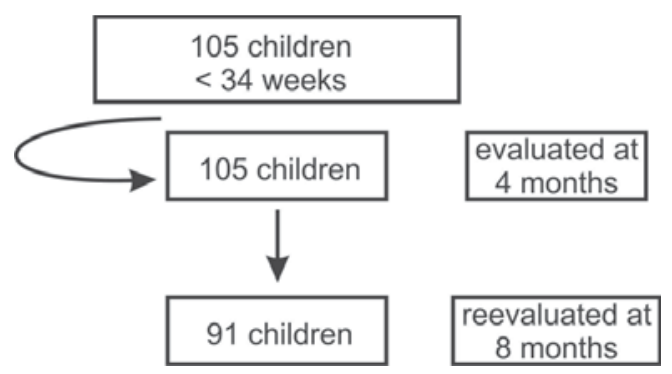

Figure 1: Shows newborn reviews

Table 1: Maternal and newborn features $n=91$

$\begin{array}{lc}\text { Variables } & \text { (\%) } \\ \text { Male gender } & 43(47.3 \%) \\ \text { Gestational age }<30 \text { weeks } & 70(76.9 \%) \\ \text { Birth weight }<1.000 \mathrm{~g} & 11(12.1 \%) \\ \text { Hospitalisation period }>31 \text { days } & 55(50.9 \%) \\ \text { Classification - small for the age } & 51(56.0 \%) \\ \text { Chronic foetal suffering } & 42(46.2 \%) \\ \text { Centralisation flow } & 11(12.1 \%) \\ \text { Vaginal delivery } & 35(38.5 \%) \\ \text { Maternal age - 19-34 years old } & 64(70.3 \%) \\ \text { Socio-economic level - B2- C2 Class } & 82(90.1 \%) \\ \text { More than } 4 \text { prenatal assignments } & 71(78.0 \%) \\ \text { Hypertensive alterations during pregnancy } & 45(49.5 \%) \\ \text { Prenatal corticotherapy } & 61(67.0 \%) \\ \text { Reanimation in delivery room } & 68(74.7 \%)\end{array}$

Table 2: Newborns' postnatal features $n=91$

Variables

Hialyne embrane disease

Surfactant use

Antoniotic use

Amines use

Mechanical ventilation use

Bronchopulmonary dysplasia

Forwarded in 4 months

Forwarded in 4 months with intervention

Mom caretaker after discharge

Hospitalisation - only maternal milk
(\%)

$61(67.0 \%)$

$43(47.3 \%)$

$77(84.6 \%)$

$32(35.2 \%)$

$33(36.3 \%)$

$7(7.7 \%)$

$57(62.6 \%)$

45 (49.5\%)

70 (76.9\%)

$53(58.2 \%)$ 
man approved this study. The children were included only after signatures from parents in the free informed consent form were obtained.

All children born less than 34 weeks who remained hospitalised in the Neonatal Progressive Care Unit and that had a consultation in the hospital Follow-up Clinic during the study period were included. We excluded children with genetic syndromes, malformations, diagnosed neurological disorders (peri-intraventricular hemorrhage grades III and IV; encephalomalacia) and Apgar score $<7$ at five minutes; children born of multiple foetuses pregnancy; deaf; blind; on systematic intervention with

Table 3: Variables for mothers and newborns of $\leq 34$ weeks related to integral child development

\begin{tabular}{|c|c|c|c|c|c|c|}
\hline Variable & $\begin{array}{c}\text { Maintained } \\
\text { delay } \\
\text { development } \\
n=9(\%)\end{array}$ & $\begin{array}{c}\text { Worse } \\
\text { development } \\
\text { n = } 3(\%)\end{array}$ & $\begin{array}{c}\text { Maintained } \\
\text { adequate } \\
\text { development } \\
n=31(\%)\end{array}$ & $\begin{array}{c}\text { Proper } \\
\text { development } \\
n=48(\%)\end{array}$ & $n=91$ & Value \\
\hline \multicolumn{7}{|l|}{ Gender } \\
\hline Male & $3(7.0 \%)$ & $2(4.7 \%)$ & $15(34.9 \%)$ & $23(53.4 \%)$ & 43 & $0.751^{1}$ \\
\hline Female & $6(12.5 \%)$ & $1(2.1 \%)$ & $16(33.3 \%)$ & $25(52.1 \%)$ & 48 & \\
\hline \multicolumn{7}{|l|}{ Gestational Age } \\
\hline$<30$ & $5(7.1 \%)$ & $2(2.9 \%)$ & $25(35.7 \%)$ & $38(54.3 \%)$ & 70 & $0.451^{1}$ \\
\hline$\geq 30$ & $4(19.0 \%)$ & $1(4.8 \%)$ & $6(28.6 \%)$ & $10(47.6 \%)$ & 21 & \\
\hline \multicolumn{7}{|l|}{ Weight at birth } \\
\hline$<1000 \mathrm{~g}$ & $5(45.5 \%)^{* *}$ & $1(9.1 \%)$ & $2(18.2 \%)$ & $3(27.3 \%)$ & 11 & \\
\hline$\geq 1000$ & $4(5 \%)^{*}$ & $2(2.5 \%)$ & $29(36.3 \%)$ & $45(56.2 \%)$ & 80 & $0.002^{1}$ \\
\hline \multicolumn{7}{|l|}{ Classification } \\
\hline SGA & $8(15.7 \%)$ & $2(3.9 \%)$ & $15(29.4 \%)$ & $26(51.0 \%)$ & 51 & \\
\hline AGA & $1(2.5 \%)$ & $1(2.5 \%)$ & $16(40 \%)$ & $22(55.0 \%)$ & 40 & $0.397^{1}$ \\
\hline \multicolumn{7}{|l|}{$\begin{array}{c}\text { Socioeconomic } \\
\text { level }\end{array}$} \\
\hline De E & $2(22.2 \%)$ & $0(0.0 \%)$ & $4(44.4 \%)$ & $3(33.3 \%)$ & 9 & $0.397^{1}$ \\
\hline B2- C2 & $7(8.5 \%)$ & $3(3.7 \%)$ & $27(32.9 \%)$ & $45(54.9 \%)$ & 82 & \\
\hline \multicolumn{7}{|c|}{ Antenatal corticosteroids } \\
\hline Yes & $7(11.5 \%)$ & $1(1.6 \%)$ & $21(34.4 \%)$ & $32(52.5 \%)$ & 61 & $0.644^{1}$ \\
\hline No & $1(4.2 \%)$ & $1(4.2 \%)$ & $8(33.3 \%)$ & $14(58.3 \%)$ & 24 & \\
\hline
\end{tabular}

1 - Exact Pearson's chi - squared test ; * adjusted residual $<-1.96,{ }^{* *}$ adjusted residual $>1.96$.

Table 4: Variables for mothers and newborns of $\leq 34$ weeks related to integral child development

\begin{tabular}{|c|c|c|c|c|c|c|}
\hline Variable & $\begin{array}{c}\text { Maintained } \\
\text { delay } \\
\text { development } \\
n=9(\%)\end{array}$ & $\begin{array}{c}\text { Worse } \\
\text { development } \\
n=3(\%)\end{array}$ & $\begin{array}{c}\text { Maintained } \\
\text { adequate } \\
\text { development } \\
n=31(\%)\end{array}$ & $\begin{array}{c}\text { Proper } \\
\text { development } \\
n=48(\%)\end{array}$ & $n=91$ & Value \\
\hline \multicolumn{7}{|l|}{ Hyaline membrane disease } \\
\hline Yes & $6(9.8 \%)$ & $2(3.3 \%)$ & $20(32.8 \%)$ & $33(54.1 \%)$ & 61 & $0.975^{1}$ \\
\hline No & $3(10.0 \%)$ & $1(3.3 \%)$ & $11(36.7 \%)$ & $15(50.0 \%)$ & 30 & \\
\hline \multicolumn{7}{|l|}{ Use of surfactant } \\
\hline Yes & $6(14.0 \%)$ & $2(4.7 \%)$ & $12(27.9 \%)$ & $23(53.5 \%)$ & 43 & $0.492^{1}$ \\
\hline No & $3(6.3 \%)$ & $1(2.1 \%)$ & $19(39.6 \%)$ & $25(52.1 \%)$ & 48 & \\
\hline \multicolumn{7}{|l|}{ Use de amines } \\
\hline Yes & $6(18.8 \%)$ & $0(0.0 \%)$ & $12(37.5 \%)$ & $14(43.8 \%)$ & 32 & $0.088^{1}$ \\
\hline No & $3(5.1 \%)$ & $3(5.1 \%)$ & $19(32.2 \%)$ & $34(57.6 \%)$ & 59 & \\
\hline \multicolumn{7}{|l|}{ Use of mechanical ventilation } \\
\hline Yes & $7(12.1 \%)$ & $2(3.4 \%)$ & $20(34.5 \%)$ & $29(50.0 \%)$ & 58 & $0.843^{1}$ \\
\hline No & $2(6.1 \%)$ & $1(3.0 \%)$ & $11(33.3 \%)$ & $19(57.6 \%)$ & 33 & \\
\hline \multicolumn{7}{|l|}{ Bronchopulmonary Displacy } \\
\hline Yes & $3(42.9 \%)^{* *}$ & $0(0.0 \%)$ & $3(42.9 \%)$ & & & \\
\hline No & $6(7.1 \%)^{*}$ & $3(3.6 \%)$ & $28(33.3 \%)$ & $1(14.3 \%)$ & 7 & $0.024^{1}$ \\
\hline $\begin{array}{l}\text { Follow up at } 4 \text { months without } \\
\text { intervention }\end{array}$ & & & & $47(56.0 \%)$ & 84 & \\
\hline Yes & $9(15.8 \%)^{* *}$ & $0(0.0 \%)^{*}$ & $3(5.3 \%)^{*}$ & $48(78.9 \%)^{\star \star}$ & 57 & $0.000^{1}$ \\
\hline No & $0(0.0 \%)^{*}$ & $3(8.8 \%)^{* *}$ & $31(91.2 \%)^{\star *}$ & $0(0.0 \%)^{*}$ & 31 & \\
\hline \multicolumn{7}{|l|}{ Intervention after follow up } \\
\hline Yes & $4(8.90 \%)$ & $0(0.0 \%)$ & $0(0.0 \%)$ & $41(1.1 \%)$ & 45 & $0.004^{1}$ \\
\hline No & $5(55.6 \%)$ & $0(0.0 \%)$ & $0(0.0 \%)$ & $4(4.4 \%)$ & 9 & \\
\hline \multicolumn{7}{|l|}{ Child caregiver } \\
\hline Mother & $6(8.6 \%)$ & $2(29 \%)$ & $2535.7 \%)$ & $37(2.9 \%)$ & 70 & $0.901^{1}$ \\
\hline Other & $6(14.3)$ & $1(48 \%)$ & $11(52.4 \%)$ & $11(52.4 \%)$ & 21 & \\
\hline
\end{tabular}

1 - Exact Pearson's chi - squared test ; * adjusted residual $<-1.96,{ }^{* *}$ adjusted residual $>1.96$. 
occupational therapy and/or were with physiotherapy before; and those who did not return for reassessment at eight months.

All participants were evaluated at four and eight months of corrected age by the Bayley Scales of Infant Development III - Bayley III test. The test consists of five independent scales - cognitive, language, motor, social-emotional and adaptive behaviour - and is designed to assess children between one and 42 months of age ${ }^{6}$. In this study, the children were assessed for cognitive scales, language and motor skills. The Bayley III is classified as the gold standard for assessment of neurological development of infants and is often used in research on preterm infants ${ }^{7-8}$.

The raw score, obtained by summing the items carried by the child with the items before the age at which the test was started, was converted into standard points, obtaining an index score (EI), fast performance that identifies (IE $\geq 115$ ); performance within normal limits (the IE 85 114); slightly delayed performance (i.e., 70-84); and significantly delayed (IE $\leq 69)^{6}$. Parents/ guardians were informed of the results of the test and children with scores below 85 in two or more scales were referred to a centre for rehabilitation and intervention.

The children were evaluated in two stages: at four and eight months of corrected age. At eight months they were classified into four groups: (a) deterioration in the development was considered when the child: showed a score lower than 85 in two or more scales at four months and scores below 85 in two or more scales at eight months; (b) maintained delayed development, was defined as a score remaining below 85 in two or more scales after four and eight months; (c) maintained adequate development was considered when the score was greater than 85 on two or more scales after four and eight months, and (d) improvement in the development was represented by scoring below 85 on two or more scales at four months and above 85 on two or more scales to eight months.

Evaluations lasted an average of 40 minutes and were conducted by two researchers. Before data collection, researchers were trained in the application of the Bayley scales, and verified the reliability between examiners in a sample of eight children who participated in the study. The intraclass correlation coefficient between the two raters ranged from 0.893 to 1 for the Bayley scales: cognitive, receptive language, expressive language, fine motor and gross motor.

To characterise the sample and identify risk factors for development, the following data were collected on the child's and/or maternal medical record: gender, corrected age, birth weight, chronic foetal distress, flow centralisation, type of birth, maternal age, socioeconomic status of the family, number of prenatal consultations, hypertensive disorders during pregnancy, steroid therapy, resuscitation in the delivery room, hyaline membrane disease, use of surfactant, antibiotics, amines and mechanical ventilation, bronchopulmonary dysplasia (BPD), referral to four months without intervention, referral to four months with intervention, the child's caregiver and food during hospitalisation.
As for hypertensive disorders in pregnancy eclampsia, preeclampsia and hypertensive disorders of pregnancy were considered and recorded in the patient chart. Children with birth weights below the 10th percentile were considered small for the gestational age (SGA) and the ones with birth weights between the 10th and 90th percentiles were considered adequate for the gestational age (AGA), according to the classification of Alexander et $\mathrm{al}^{9}$ were considered preterm with corrected age. Bronchopulmonary dysplasia (BPD) was defined by the need for supplemental oxygen used during more than 28 days. $^{10 .}$

Socioeconomic status, referral to four months, referral to four months with intervention, new-born caregiver and food during hospitalisation were obtained by reports from parents and/or guardians during the evaluation. Socioeconomic status was based on that of the Brazilian Association of Research Companies (BARC) $)^{11,12}$ which, by the sum of the scores obtained on the consumer goods ownership and education of the household head, classifies families into eight categories ranging from $\mathrm{A} 1$ to $\mathrm{E}$, with $\mathrm{A} 1$ being the highest and $\mathrm{E}$ the lowest.

The qualitative variables were characterised in terms of percentages. In the analysis of the association between the variables and the overall improvement the chi-square test of Pearson asymptotic (when $20 \%$ of the expected values were between one and five and $80 \%$ of the expected were above five) and chi-square exact Pearson (when more than $20 \%$ of the expected values were between one and five) were used. For analyses that had $\mathrm{p} \leq 0.05$, the waste values were calculated and adjusted to locate where the difference was. A positive value of residue $\geq 1.96$ indicates a table cell with the highest frequency of occurrence and a negative value of residue $\leq-1.96$ indicates a cell with a lower frequency of occurrence. For all analyses a significance level 0.05 was used. Statistical analyses were performed using SPSS version 13.0.

\section{RESULTS}

During the study period, 105 children met the inclusion criteria; 14 did not attend the revaluation to eight months. The final sample of 91 infants were assessed by the Bayley III scale at four and eight months.

The sample characteristics are explained in Table 1. Most of the infants had a gestational age lower than 30 weeks (76.9\%), birth weight above $1,000 \mathrm{~g}(53.8 \%)$; and just over half remained hospitalised for more than 31 days $(50.9 \%)$. Perinatal care and morbidities are shown in Table 2.

Regarding the development assessed according to the Bayley III test, significant association was found with birth weight, BPD and the systematic intervention after referral. It was observed that $45.5 \%$ of children born weighing less than 1,000 grams and $42.9 \%$ of BPD remained in the delayed development category at eight months. In total $91.1 \%$ of children received the intervention and showed improvement in development according to the Bayley test (Tables 3 and 4). Thus, the birth weight and BPD are associated with worsening development in the first year of life, while the systematic intervention is related to enhancing human development. 


\section{DISCUSSION}

Birth weight, presence of BPD and systematic intervention after referral were identified as variables related to the improvement or deterioration in development at eight months corrected gestational age born premature at 34 weeks or less.

Birth weight was shown to have significant impact on development, with $45.5 \%$ of infants weighing less than $1,000 \mathrm{~g}$ remaining developmentally delayed at eight months, while in the group of children born with more than $1,000 \mathrm{~g}$, only $4.1 \%$ continued with delayed development. Birth weight is a major factor in neonatal complications and is even considered a predictor of delayed development ${ }^{13}$.

The BPD has been identified as a variable that can compromise development; $42.9 \%$ had developmental delay while only $7.1 \%$ of children without this diagnosis remained delayed. There is evidence that BPD is a factor for predisposition to changes in psychomotor development in premature infants at six months of corrected gestacional age $^{14}$. BPD incidence increases the delay in development, independent of other risk factors. According to this study, children with BPD were four times more likely to change in motor development before six months of corrected gestational age compared to children without BPD. Children born weighing less than $1,000 \mathrm{~g}$ were examined using the Bayley test $\mathrm{III}^{15}$ between 18 and 22 months and showed changes in development rates significantly higher in the presence of BPD. The severity and chronicity of BPD are predictors of motor deficit at two years of age ${ }^{16-17}$.

The BDP is caused by the failure of immature lungs to achieve structural complexity and is one of the most important sequelae of prematurity ${ }^{17}$ BPD is considered a chronic lung disease of prematurity, with high incidence in newborns of very low birth weight $(<1,000 \mathrm{~g})^{16-17}$.

Intervention after referral was an important impact variable for improvement in development at eight months of GCA; $91.1 \%$ of referred children who received some type of intervention improved their developmental delay. Intervention was considered any systematic monitoring with rehab professionals: physiotherapist, speech therapist, neurologist, psychologist and occupational therapist. The data show that having identified the developmental delay and starting the intervention, children achieved significant improvement. This reinforces the im- portance of follow-up with the use of standardised scales to delay identification of children at risk. The data also reinforce the importance of referral and intervention to identify developmental delay.

Meta-analysis on the effectiveness of intervention in the motor and/or cognitive development of children born prematurely showed randomised studies and clinical trials of intervention programs in the first year of life of preterm infants. Early intervention at this stage of life has a significant impact on child development ${ }^{17}$.

In a systematic review conducted to investigate the effects of the intervention in children at risk of developmental delay, the results revealed statistically significant gains in the development of children receiving sensory and motor stimulation ${ }^{18}$. Nordhov et al. ${ }^{18}$ examined the effectiveness of an intervention program in behaviour to five years of age in children born with low weight. Parents in the intervention group reported fewer behavioural problems, confirming the long-term effects of intervention programs.

In this study we observed that identification of level of development, referral and appropriate intervention have striking associations with improved overall performance at eight months of children born with GI less than or equal to 34 weeks by Bayley III test. Parallel to these findings, it is important to consider brain plasticity in development recovery ${ }^{19}$.

A limitation of the study was the lack of analysis of the variables smoking, illicit drug use, alcohol during pregnancy and maternal educational level because of the inconsistency of the data. The sample was smaller when considering the number of children in the subgroups worsening in development, maintained late development, maintained proper development and improvement effort.

The study highlighted the importance of monitoring premature infants with IGC at or below 34 weeks who are discharged from the hospital. The monitoring enables identification and referral for intervention in this group of children. Birth weight below 1,000 grams and DBP are the main predictive factors for developmental delay, while the systematic intervention is the main factor related to the improvement effort. Given these findings, it is important to provide timely support to populations in vulnerable situations, by public policies, institutions offering follow up care of children and intervention when necessary.

\section{REFERENCES}

1. Borba GG, Neves ET, Arrué AM, Silveira A, Zamberlan KC. Fatores associados à morbimortalidade neonatal: um estudo de revisão. Rev Saúde. 2014; 40(1): 9-16. DOI: http://dx.doi.org/10.5902/223658347774

2. Wilson-Costello D, Friedman H, Minich N, Siner B, Taylor G, Schluchter M, et al. Improved neurodevelopmental outcomes for extremely low birth weight infants in 2000-2002. Pediatrics. 2007; 119(1): 37-45. DOI: http://dx.doi.org/10.1542/peds.2006-1416

3. Silva J, Fronio JS, Lemos RA, Ribeiro LC, Aguiar TS, Silva TD, et al. Oportunidades de estimulação no domicílio e habilidade funcional de crianças com potenciais alterações no desenvolvimento. J Human Growth Dev. 2015; 25(1): 19-26. DOI: http://dx.doi.org/10.7322/jhgd.96763

4. Moster D, Lie RT, Markestad T. Long-term medical and social consequences of preterm birth. $\mathrm{N}$ Engl $\mathrm{J}$ Med. 2008; 359: 262-73. DOI: http://dx.doi.org/10.1056/NEJMoa0706475 
5. Martinez CMS, Joaquim RHVT, Oliveira EB, Santos IC. Suporte informacional como elemento para orientação de pais de pré-termo: um guia para o serviço de acompanhamento do desenvolvimento no primeiro ano de vida. Rev Bras Fisioter. 2007; 11(1): 73-81. DOI: http://dx.doi.org/10.1590/S141335552007000100012

6. Bayley N. Bayley scales of infant and toddler development. San Antonio, TX: Psychological Corporation; 2006; p. 266.

7. Houtzager BA, Gorter-Overdiek B, Van Sonderen L, Tamminga P, Van Wassenaer AG. Improvement of developmental outcome between 24 and 36 months corrected age in very preterm infants. Acta Paediatr. 2010; 99(12): 1801-6. DOI: http://dx.doi.org/10.1111/j.1651-2227.2010.01953.x

8. Claas MJ, Bruinse HW, Koopman C, van Haastert IC, Peelen LM, de Vries LS. Two-year neurodevelopmental outcome of preterm born children $\leq 750 \mathrm{~g}$ at birth. .Arch Dis Child Fetal Neonatal Ed. 2011; 96(3): F16977. DOI: http://dx.doi.org/10.1136/adc.2009.174433

9. Alexander GR, Himes JH, Kaufman RB, Mor J, Kogan M. A United States national reference for fetal growth. Obstet Gynecol. 1996; 87(2): 163-8. DOI: http://dx.doi.org/10.1016/0029-7844(95)00386-X

10. Jobe AH, Bancalari E. Bronchopulmonary dysplasia. Am J Respir Crit Care Med. 2001; 163(7): 1723-9. DOI: http://dx.doi.org/10.1164/ajrccm.163.7.2011060

11. Associação Brasileira de Empresas de Pesquisa (ABEP). Critério de classificação econômica no Brasil, 2008. [cited 2010 Aug 07] Available from: http://www.abep.org/novo/Content.aspx?ContentID=302.

12. De Kieviet JF, Piek JP, Aarnoudse-Moens CS, Oosterlaan J. Motor development in very preterm and very low-birth-weight children from birth to adolescence: a meta-analysis. JAMA. 2009; 302(20): 2235-42. DOI: http://dx.doi.org/10.1001/jama.2009.1708

13. Martins PS, Mello RR, Silva KS. Bronchopulmonary dysplasia as a predictor factor for motor alteration at 6 months corrected age in premature infants. Arq Neuropsiquiatr. 2010; 68(5): 749-54. DOI: http://dx.doi. org/10.1590/S0004-282X2010000500014

14. Natarajan G, Pappas A, Shankaran S, Kendrick DE, Das A, Higgins RD, et al. Outcomes of extremely low birth weight infants with bronchopulmonary dysplasia: Impact of the physiologic definition. Early Hum Dev. 2012; 88(7): 509-15. DOI: http://dx.doi.org/10.1016/j.earlhumdev.2011.12.013

15. Araújo ATC, Eickmann SH, Coutinho SB. Fatores associados ao atraso do desenvolvimento motor de crianças prematuras internadas em unidade de neonatologia. Rev Bras Saúde Matern Infant. 2013; 13(2): 119-28. DOI: http://dx.doi.org/10.1590/S1519-38292013000200005

16. Spittle AJ, Doyle LW, Boyd RN. A systematic review of the clinimetric properties of neuromotor assessments for preterm infants during the first year of life. Dev Med Child Neurol. 2008; 50(4): 254-66. DOI: http://dx.doi.org/10.1111/j.1469-8749.2008.02025.x.

17. Blauw-Hospers $\mathrm{CH}$, Hadders-Algra M.. A systematic review of the effects of early intervention on motor development. Dev Med Child Neurol. 2005; 47(6): 421-32.

18. Nordhov SM, Rønning JA, Ulvund SE, Dahl LB, Kaaresen PI. Randomized controlled trial early intervention improves behavioral outcomes for preterm infants. Pediatrics. 2012; 129(1): e9-e16. DOI: http:// dx.doi.org/10.1542/peds.2011-0248

19. Anderson V, Spencer-Smith M, Wood A. Do children really recover better? Neurobehavioural plasticity after early brain insult. Brain. 2011; 134(Pt 8): 2197-221. DOI: http://dx.doi.org/10.1093/brain/awr103

This article is distributed under the terms of the Creative Commons Attribution 4.0 International License (http://creativecommons.org/licenses/by/4.0/), which permits unrestricted use, distribution, and reproduction in any medium, provided you give appropriate credit to the original author(s) and the source, provide a link to the Creative Commons license, and indicate if changes were made. The Creative Commons Public Domain Dedication waiver (http://creativecommons.org/publicdomain/zero/1.0/) applies to the data made available in this article, unless otherwise stated. 


\section{Resumo}

Introdução: Os grandes avanços na assistência perinatal resultaram em maior sobrevida de recémnascidos com peso ao nascimento cada vez mais baixo. No entanto, essas crianças têm elevado risco de apresentar alterações no desenvolvimento.

Objetivo: Analisar a relação entre as variáveis perinatais e o desenvolvimento global de crianças prematuras aos quatro e oito meses de idade corrigida.

Método: Estudo longitudinal coorte prospectivo em que foram acompanhadas 91 crianças nascidas prematuras com idade gestacional (IG) igual ou abaixo de 34 semanas. As crianças foram avaliadas aos quatro e aos oito meses pelas escalas cognitiva, de linguagem e motora do Bayley Scales of Infant Development III.

Resultados: O peso ao nascimento e a displasia broncopulmonar foram identificados como fatores para a permanencia no atraso no desenvolvimento global. A intervenção após encaminhamento foi identificado como fator para a melhora no desenvolvimento.

Conclusão: O peso ao nascimento abaixo de 1.000 gramas e a displasia broncopulmonar foram os principais fatores preditivos para o atraso no desenvolvimento. A intervenção sistemática foi fator preditivo para a melhora no desenvolvimento.

Palavras-chave: Prematuro, Desenvolvimento Infantil, Fatores de Risco. 